\title{
Impact of biofertilizers on resistance to diseases of spring barley
}

\author{
Irina Tychinskaya ${ }^{1}$, Alexey Tarakin $^{2}$, Yuriy Bukhvostov ${ }^{2}$ Irina Minakova ${ }^{3}$, and Tatyana \\ Bukreeva $^{3, *}$ \\ ${ }^{1}$ Federal Scientific Center of Legumes and Groat Crops, Molodezhnaya str., 10, buil.1, poselok \\ Streletski, 302502 Orel region, Russia \\ ${ }^{2}$ Orel State Agrarian University named after N.V. Parakhin, Generala Rodina str., 69, 302019 Orel, \\ Russia \\ ${ }^{3}$ Southwest State University, 50 let Oktyabrya str., 94, 305040 Kursk, Russia
}

\begin{abstract}
The article is devoted to the effect of biofertilizers (Bioklad and Vermix) on the severity of common diseases of spring barley in field trials conducted in the Orel region. The authors estimate risks of spring barley diseases and analyse the results of the three-year experiment, carried out under certain weather and climate conditions. The subject of the research is the spring barley crop Suzdalets under intensive farming (zoned for 2, 3, 5 regions of Russia). For a more comprehensive assessment, the experimental process includes separate and combined application of biofertilizers at two different doses. The results of the experiment shows that spring barley crops have responded to all tested combinations of treatment and, at the same time, biofertilizers Bioklad and Vermix, regardless of the doses of application used, had a positive treatment effect and reduced development of severe plant diseases such as root rot by $8.4 \%$, Helminthosporium spot by $29.2 \%$, powdery mildew by $28.9 \%$, Rhynchosporium by $26.3 \%$, stem rust by $65.9 \%$, Septoria spot by $24.4 \%$, and Fusarium head blight by $12 \%$. The most productive agrocenosis of spring barley was formed with the use of Bioklad: barley yield was $0.59 \mathrm{t} / \mathrm{ha}$ at a dose of $1 \mathrm{~L} / \mathrm{ha}$ and $0.61 \mathrm{t} / \mathrm{ha}$ at a dose of 2 $\mathrm{L} / \mathrm{ha}$.
\end{abstract}

\section{Introduction}

Barley (Hordeum vulgare L.) is one of the main crops in Russia and in the world. Barley has a fairly large share in terms of gross yield and sown areas. Barley grain has $11-15 \%$ of protein and $50-60 \%$ of starch. Barley protein contains all essential amino acids, a large amount of iron, calcium, potassium salts, phosphorus, and magnesium, and accounts for $80 \%$ of grain production for fodder purposes [1-3]. According to Rosstat, in 2019, the gross yield for barley in Russia amounted to 20489 thousand tons, which is $20.6 \%$ more than in 2018 , while the sown area increased by $5.6 \%$.

${ }^{*}$ Corresponding author: tnbinchina@yandex.ru 
Plant disease susceptibility is one of the factors that lead to grain yield losses and spring barley is no exception. Grain diseases significantly reduce productivity and seed germination, as well as grain quality [4]. Diseases can reduce grain yield by $30-40 \%$.

Recently, science and experts in applied agriculture have been focusing their attention on resource-conserving technologies for grain farming, which include the biologization (greening) of agriculture. The biologization of agriculture is aimed at restoring soil fertility, improving physical and chemical properties of soil, and increasing yields [5-9]. The use of biofertilizers is an effective way to resolve these problems [10,11]. Biofertilizers intensify physiological and biochemical processes in plants and at the same time increase resistance to stress and diseases. As a substance of living micro-organisms, it is directly involved in plant metabolism without adverse environmental impacts. Bioklad and Vermix belong to this type of biofertilizers.

In this regard, the purpose of the research is to study the effect of biofertilizers Bioklad and Vermix on the main diseases and yield of spring barley Suzdalets in the conditions of the Orel region.

\section{Materials and Methods}

The laboratory research was carried out at the Orel State Agrarian University, and the field trials took place in the Research, Educational and Development Center 'Integration' (Orel region, Russia) between 2017 and 2019. The plants were grown in a seven-field system of crop rotation on $10 \mathrm{~m} 2$ plots with four replicates. Arrangement of experimental plots is systematic and the seed rate of Suzdalets was $225 \mathrm{~kg} / \mathrm{ha}$. According to the Orel Center of Chemization and Agricultural Radiology, the soil of the experimental plots has a high proportion of exchangeable potassium $(14.8 \mathrm{mg} / 100 \mathrm{~g})$ and mobile phosphorus $(11.7 \mathrm{mg} /$ $100 \mathrm{~g}$ ), average humus content (3.7\%) and soil $\mathrm{pH}(5.0)$. Two types of biofertilizers, Bioklad and Vermix, were used for the experiments. Both biofertilizers have a protective and stimulating effect. Bioklad contains two types of animal manure, humus, mineral ingredients, glauconite, boron, extract of silver-fir, 12 types of enzymes and about 20 microorganisms, etc. Glauconite improves soil texture; it preserves and accumulates moisture and soil biota. Vermix, based on cow manure, alkaline extraction, mineral ingredients, humic acids and fulvic acids, activates the natural resistance of plants to diseases and pests and prevents plant pathogen infections. Biofertilizers were applied (foliar application) at two doses: 1 liter per hectare and 2 liters per hectare.

Table 1. Tested combinations of treatment.

\begin{tabular}{|l|l|}
\hline \multicolumn{1}{|c|}{$1,0 \mathrm{~L} / \mathrm{ha}$} & \multicolumn{1}{c|}{$2,0 \mathrm{~L} / \mathrm{ha}$} \\
\hline 1. Control* & 1. Control* \\
\hline 2. Bioklad & 2. Bioklad \\
\hline 3. Vermix & 3. Vermix \\
4. Bioklad +Vermix & 4. Bioklad +Vermix \\
\hline
\end{tabular}

*Control - without application of biofertilizers

The growing seasons of 2017-2019 were characterized by high-contrast climatic conditions; it has allowed giving an objective assessment of the applied combinations of treatment.

Disease severity of plants was estimated by examining the plant surface covered with the impaired areas. The level of severity is assessed according to special scales, and is expressed in points or percentage under the recommendations of Stepanov and Chumakov.

Grain yield was measured by weighing grain harvested from each plot by direct combining with TERRION machines. 
The obtained experimental data were analysed using the methodological recommendations of $\mathrm{B}$. Dospekhov and XLSTAT software for statistical analysis in MS Excel.

In conditions of excessive application of mineral and organic fertilizers, it is becoming more relevant to use the renewable biological resources, supporting the mechanisms of selfregulation and the circulation of biophilic elements in the agroecosystem. Crop production consumes about $20-80 \%$ of the total biomass in agroecosystem, the rest is a waste product, which can, and should be, returned to the agroecosystem as organic residues [12].

Science and industry prove the existence of a direct relationship between soil fertility, application of fertilizers, crop yields and gross yield of crop products [13]. The world and domestic agriculture experience shows that organic fertilizers play a significant role in soil fertility restoration [14]. Unlike mineral fertilizers, which acidify soil, organic fertilizers are based on humic compounds formed during processing in a liquid substrate [15].

Thus, organic fertilizers are the main source of humus; they improve agrochemical, physical, mechanochemical and fertile properties of soil.

\section{Results}

Barley is affected by numerous fungal, bacterial and viral diseases. These diseases reduce grain yield. The most widespread disease of barley is root rot. Average barley losses caused by root rot are $15 \%$, and losses for some years can amount to $50 \%$ and even more (Peresypkin, 1989).

The result of the experiment has shown that the widest spread of root rot was in 2018, but it did not exceed $2.0 \%$.

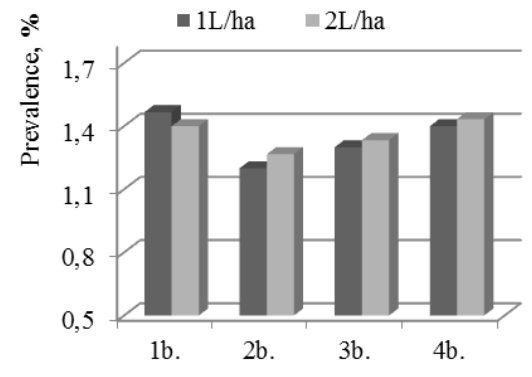

a)

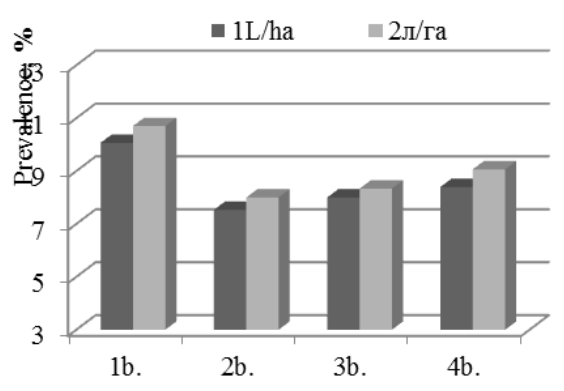

b)

Fig. 1. Prevalence a) root rot b) Rhynchosporium of spring barley crops Suzdalets, depending on treatment used, \% (field trials based on the Research, Educational and Development Center 'Integration', average in the period of 2017-2019)

Rhynchosporium infection of spring barley crops occurred annually, which spread extensively in 2018 but waned in 2019. In 2017, it was detected in low levels.

Among leaf diseases of barley, leaf blight (Helminthosporium spot) has regularly appeared during the experiment. As for Septoria leaf spots, the disease severity of $5-10 \%$ of damaged plants appeared at the seedling stage and during the heading stage. 


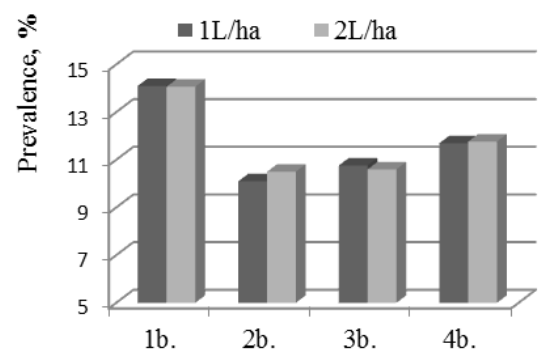

a)

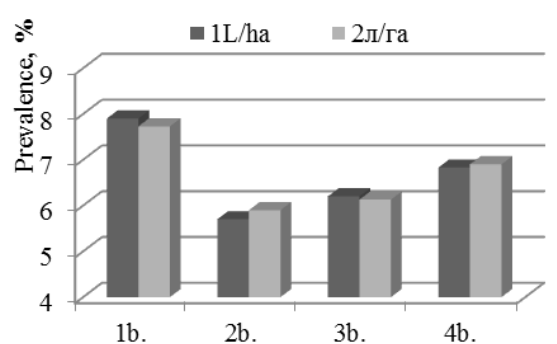

b)

Fig. 2. Prevalence a) Helminthosporium spot b) Septoria leaf spot in spring barley crops Suzdalets, depending on treatment used, \% (field trials based on the Research, Educational and Development Center 'Integration', average in the period of 2017-2019)

Helminthosporium spot disease waned after the use of new types of biofertilizers. The effectiveness of the biofertilizers was statistically confirmed.

The prevalence of powdery mildew and stem rust on barley crops is consistently low. In 2017, due to high air temperature and lack of moisture during the growing season, the spring barley plants were minimally affected by powdery mildew and stem rust (Fig. 3). Powdery mildew almost failed to develop on crops of spring barley (Fig. 3).
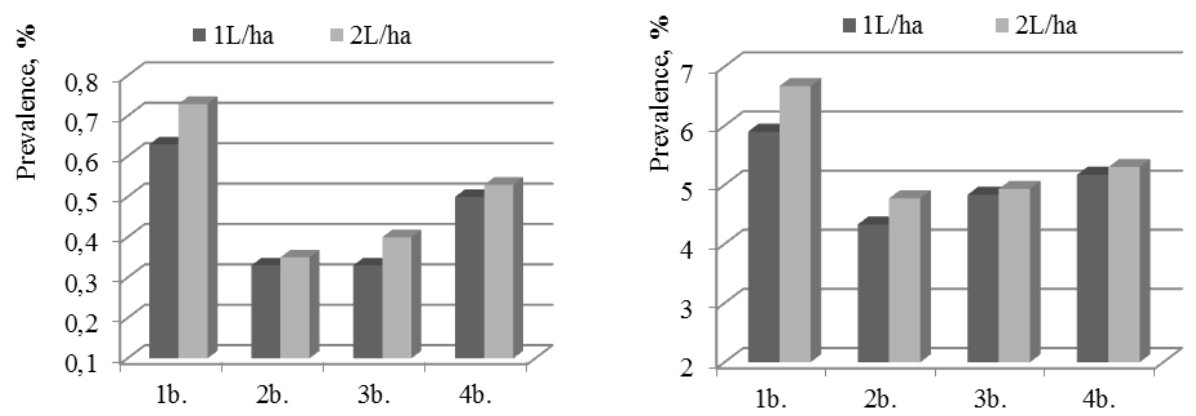

Fig. 3. Prevalence a) stem rust b) powdery mildew in spring barley crops Suzdalets, depending on treatment used, \% (field trails based on the Research, Educational and Development Center 'Integration', average in the period of 2017-2019)

The results of the three-year experiment have shown that the spring barley crop Suzdalets responded to all tested combinations of treatment used during the period 2017-2019 (See table 2).

Table 2. Yield of the spring barley crop Suzdalets in different years of experiment, depending on the tested combinations of treatment used, $\mathrm{t} / \mathrm{ha}$.

\begin{tabular}{|l|c|c|c|c|}
\hline $\begin{array}{l}\text { Tested } \\
\text { treatment }\end{array}$ & $\mathbf{2 0 1 7}$ & $\mathbf{2 0 1 8}$ & $\mathbf{2 0 1 9}$ & $\begin{array}{c}\text { Average in three } \\
\text { years }\end{array}$ \\
\hline \multicolumn{5}{|c|}{$\mathbf{1 . 0}$ L/ha } \\
\hline 1. Control & 3.68 & 4.49 & 4.56 & 4.24 \\
\hline 2. Bioklad & 4.46 & 4.92 & 5.10 & 4.83 \\
\hline 3. Vermix & 4.40 & 4.80 & 4.89 & 4.70 \\
\hline $\begin{array}{l}\text { 4.Bioklad }+ \\
\text { Vermix }\end{array}$ & 4.48 & 4.90 & 4.93 & 4.77 \\
\hline \multicolumn{1}{|c|}{$\mathrm{HCP}_{0,5}$} & 0.6 & 0.4 & 0.3 & - \\
\hline \multicolumn{5}{|l|}{$\mathbf{2 , 0 ~ \mathbf { h a }}$} \\
\hline 1. Control & 3.69 & 4.57 & 4.63 & 4.30 \\
\hline
\end{tabular}




\begin{tabular}{|l|c|c|c|c|}
\hline 2. Bioklad & 4.58 & 4.95 & 5.22 & 4.91 \\
\hline 3. Vermix & 4.51 & 4.89 & 4.99 & 4.80 \\
\hline $\begin{array}{l}\text { 4.Bioklad }+ \\
\text { Vermix }\end{array}$ & 4.61 & 4.94 & 5.14 & 4.90 \\
\hline \multicolumn{1}{|c|}{$\mathrm{HCP}_{0.5}$} & 0.8 & 0.3 & 0.3 & - \\
\hline
\end{tabular}

\section{Discussion}

The experiment has shown that root rot caused the most severe damage to spring barley on Control plots without application of any biofertilizers. We explain this result with the fact that crops weakened by lack of moisture and nutrients were more susceptible to infection. With the combined use of Bioklad and Vermix, the prevalence of the disease was less, but this combination of biofertilizers did not show as positive an effect as during the use of one of biofertilizers. A similar effect was demonstrated with the doubled application $(2 \mathrm{~L} / \mathrm{ha})$ of biofertilizers.

Rhynchosporium disease of the spring barley crops occurred annually, the peak level of the disease being in 2018, and the spread of the disease was less extensive in 2019. In 2017, the disease was detected in isolated and localized areas; the prevalence of the disease was 1$1.5 \%$.

The first symptoms of leaf diseases appeared at seedling stage. High prevalence of the disease with a rate of 5-20\% was noted in 2019 and at the stage of grain filling on the first sub-flag leaf, it amounted to $18.5 \%$.

Use of Bioklad at a dose of $1 \mathrm{~L} /$ ha reduced the prevalence of Helminthosporium spot disease by $4.2 \%$, compared with $3.6 \%$ of Control and Vermix result. The combined use of biofertilizers also had a significant impact, but at a lower level.

Under favourable weather conditions in 2017-2019, there was a moderate level of severity of Septoria leaf spot disease on crops of spring barley. At the stage of grain filling on the first sub-flag leaf, disease prevalence was rated from 3.5 up to $11.2 \%$ with the intensity of transmission from 1.5 to $7.5 \%$. The lowest level of infection development was in 2018 .

The development of powdery mildew and stem rust on barley crops was slight. Due to high air temperature and lack of moisture during the growing season in 2017, the spring barley plants were minimally affected by powdery mildew and stem rust.

During the experiment, Fusarium head blight was not widely distributed. This situation was observed throughout the testing period (2017-2019). Application of Bioklad and Vermix was effective against Fusarium head blight on barley crops, the increasing application rates of biofertilizers had the same positive effect.

The results of the three-year experiment have shown that the spring barley crop Suzdalets responded to all tested combinations of treatment used during the period 2017-2019. Use of Bioklad was the most effective at any dose during the whole testing period. On average, maximum increase in spring barley yield amounted to $0.59 \mathrm{t} /$ ha at a dose of $1 \mathrm{~L} /$ ha and 0.61 $\mathrm{t} / \mathrm{ha}$ at a dose of $2 \mathrm{~L} / \mathrm{ha}$, compared to control treatment. Use of Bioklad and Vermix mixture also showed an increase in yield where grain yield per hectar, on average, exceeded control tretment results by $0.53 \mathrm{t} / \mathrm{ha}$ at a dose of $1 \mathrm{~L} / \mathrm{ha}$ and $0.60 \mathrm{t} / \mathrm{ha}$ at a dose of $2 \mathrm{~L} / \mathrm{ha}$. Use of Vermix also showed a positive effect on spring barley yield, but the resuts were lower compared to the aforementioned combinations, therefore, on average, increase in yield was $0.46 \mathrm{t} / \mathrm{ha}$ at a dose of $1 \mathrm{~L} / \mathrm{ha}$ and $0.5 \mathrm{t} / \mathrm{ha}$ at a dose of $2 \mathrm{~L} / \mathrm{ha}$ compared to control treament.

\section{Conclusion}

The results of the experiment on the Suzdalets spring barley crops have demonstrated that biofertilizers Bioklad and Vermix, regardless of the doses of application used, had a positive 
treatment effect and reduced development of root rot, Helminthosporium spot, powdery mildew, Septoria spot, sterm rust, and Fusarium head blight. The most productive agrocenosis of spring barley were formed with use of Bioklad: barley yield was $0.59 \mathrm{t} / \mathrm{ha}$ at a dose of $1 \mathrm{~L} /$ ha and $0.61 \mathrm{t} / \mathrm{ha}$ at a dose of $2 \mathrm{~L} / \mathrm{ha}$.

\section{References}

1. A. Alabushev, E. Filippov, V. Scherbakov, N. Yankovski, E. Revyakin, G. Gogolev, Advanced resource-saving technology for the production of spring barley, 60 (Moscow, Rosinformmagtekh, 2009)

2. V. Sidorenko, D. Naumkin, V. Kostromicheva, Z. Starikova, F. Uhova, Prospects for breeding naked barley and oats in Central Russia, Legumes and groat crops 1(17), 7883 (2016)

3. V. Maksimov, G. Vinogradov, R. Zolotareva, L. Ivanova, Spring barley is the main fodder crop of the Republic of Mari El. Vestnik of the Kazan State Agrarian University, 1(39), 22-26 (2016) doi: 10.12737/19301

4. T. Sheshegova, I. Shchennikova, L. Shchekleina, L. Kokina, Sources of spring barley resistance to helminthosporium and its use in breeding, Agricultural Science EuroNorth-East 5(54), 9-14 (2016) doi: 10.30766/2072-9081.2016.54.5.09-14

5. Y. Bobkova, N. Abakumov, Influence of tillage methods on its biological activity and yield of spring barley, Agrobiznes and ecologia 2(2), 8-10 (2015) doi: 10.18551/rjoas.2015.e-conf

6. D Eremin, Changes in the content and quality of humus in leached chernozem of the Trans-Ural forest-steppe zone under the impact of their agricultural use, Eurasian Soil Science 5(49), 584-592 (2016) doi: 10.7868/S0032180X1605004X

7. A. Zelenov, I. Sycheva, A. Zorov, The action of fertilizers and mycorrhiza on vetch spring on gray forest loam soil, Proceedings of International Scientific and Practical EConference on Agriculture and Food Security Anthropogenic evolution of modern soils and food production under changing of soil and climatic conditions 2(2), 263-265 (2015) doi: 10.18551/rjoas.2015.e-conf

8. V. Lobkov, S. Plygun, A. Zolotukhin, Soil and biological aspects of a biologization of modern agriculture. Russian Journal of Agricultural and Socio-Economic Sciences 1(49), 67-72 (2016) doi:10.18551/rjoas.2016-01.08

9. K. Wilkinson, W. P. Grant, L. E. Green, S. Hunter, M. J. Jeger, P. Lowe, G. F. Medley, P. Mills, J. Phillipson, G. M. Poppy, J. Waage, Infectious diseases of animals and plants: an interdisciplinary approach, Philosophical Transactions: Biological Sciences 366, 1933-1942 (2011)

10. E. Mikhalev, A. Ivenin, V. Gorbunov, Effect of different forms and doses of organic fertilizers on the yield of spring barley on light-gray forest soils under the right bank of the Nizhegorodskaya oblast', Agrarian Russia 5, 27-29 (2011) doi: 10.30906/19995636-2011-5-27-29

11. N. Pržulj, M. Mirosavljević, P. Čanak, M. Zorić, J Boćanski, Evaluation of Spring Barley Performance by Biplot Analysis. Cereal Research Communications 43(4), 692-703 (2015) doi:10.2307/24689523

12. D. Dubovik, D. Vinogradov, Grain quality of winter wheat depending on agricultural methods under different weather conditions, Achievements of science and technology of AIC 29(2), 30-32 (2015) 
13. V. Okorkov, I. Semin, L. Okorkova, On the use of local organic fertilizers on grey forest soils of the Upper Volga region, Agrarian Journal of the upper Volga region 4(12), 2223 (2015)

14. I. Pigorev, S. Tarasov, Elements of biologization in cultivation technology of winter wheat, Vestnik OrelGAU 5(50), 102-108 (2014)

15. M. Vasbieva, A. Kosolapova, Changes in fertility parameters and contents of heavy metals of soddy-podzolic soils upon the long-term application of sewage sludge, Eurasian Soil Science 5(48), 580-586 (2015) doi: 10.7868/S0032180X15030132. 